Dieses Dokument ist eine Zweitveröffentlichung (Postprint) /

This is a self-archiving document (postprint):

Michael Dobler

Credibility of managerial forecast disclosure in market and regulated settings

Erstveröffentlichung in / First published in:

International Journal of Financial Services Management (IJFSM). 2008, 3(1), S. 83-98. Inderscience Online Journals. ISSN 1741-8062.

DOI: https://doi.org/10.1504/IJFSM.2008.016700

Diese Version ist verfügbar / This version is available on:

https://nbn-resolving.org/urn:nbn:de:bsz:14-qucosa2-365106 


\title{
Credibility of managerial forecast disclosure in market and regulated settings
}

\author{
Michael Dobler*
}

\begin{abstract}
This paper discusses the ability of models on cheap talk, and of audit and liability regulations, to provide analytically-based assessment of credibility of management forecast disclosure in market and regulated settings. While credibility is linked to restrictive conditions in pure market settings, regulatory enforcement does not necessarily contribute to forecast credibility. Key findings imply that ex ante approaches, including audit and tort liability in general, as well as partly verifiable disclosures supplementing the forecast and safe harbour provisions in particular can contribute to forecast credibility. Overall results suggest that the usefulness of managerial forecast disclosure should not be overestimated, as neither market nor regulatory mechanisms can overcome the problems related to non-verifiability.
\end{abstract}

This is the accepted version of the manuscript, manuscript, accepted for publication, i.e. post-review, pre-typesetting.

Paper accepted and published by Inderscience Publishers in the International Journal of Financial Services Management (IJFSM):

Dobler, Michael (2008). Credibility of managerial forecast disclosure in market and regulated settings. International Journal of Financial Services Management, Vol. 3 No. 1, pp. 83-98.

https://doi.org/10.1504/IJFSM.2008.016700

International Journal of Financial Services Management:

https://www.inderscience.com/ijfsm

Inderscience Publishers:

https://www.inderscience.com

Dr. Michael Dobler, MBR, Chair on Accounting and Auditing, Munich School of Management, Ludwig-Maximilians-University Munich, Ludwigstr. 28/RG IV, D-80539 Munich, Germany. Email: dobler@bwl.lmu.de. 


\section{Introduction}

An objective of financial reporting is to provide relevant and reliable information useful for decision taking. Apart from forward-looking elements in financial statements, managerial forecast disclosure, e.g. currently assessed in the context of market discipline according to pillar III of Basel II or Solvency II, is assumed to be highly decision-useful (Hirst et al., 2007; Till, 1980). Managerial forecast disclosure is defined as voluntary disclosure in management or risk reports, predicting a future economic outcome prior to its realisation (King et al., 1990; Ripken, 2005). In particular, investors are interested in forecasts to assess future cash flows or earnings and going concern uncertainties, assuming that the manager's private forecast information is likely to be the best available. Yet, regulators have been reluctant to require managerial forecast disclosure, because it might be less useful than assumed but may threaten disclosing managers with abusive litigation (AICPA, 1994; Dobler, 2005).

In providing relevant and reliable information, managerial forecast disclosure faces profound boundaries. Forecasts are non-verifiable ex ante, due to incomplete foresight and possibly subject to managerial manipulation. Since a manager may not truthfully reveal her private forecast information, rational users may doubt whether to believe in a disclosed forecast or not (Ijiri, 1975; Rogers and Stocken, 2005). If users do not believe in a forecast, they must ignore it. Forecast disclosure then cannot be decision-useful and is dispensable. Thus, credibility is the crux of managerial forecast disclosure. Forecast literature considers credibility in various ways. Most common is a user's perspective at an ex ante stage, i.e. when the forecast is disclosed. It refers to believability (or perceived credibility) as a perception held by users on whether or not to trust the forecast. This perception is affected by various factors apart from the disclosure 
of a specific forecast (Hutton and Stocken, 2007; Mercer, 2004) which may be made in good or in bad faith. Less common is a preparer's perspective at an ex ante stage. It refers to truthfulness of disclosure. This considers the fact whether a manager reveals her private information in a specific disclosure in good faith or not (Korn, 2004; Sunder, 2003). Finally, ex post perspectives relate to forecast accuracy when the realisation of the predicted variable is known and can be compared to the predicted outcome (Arnold and Hope, 1973; Lev and Penman, 1990). Forecast accuracy ex post, however, does not allow the assessment as to whether a published forecast was truthfully revealing private information and it cannot affect a user's decisions taken or refrained from, upon a particular forecast.

This paper takes a combined ex ante perspective. It defines credibility when a forecast is both truthfully disclosed, i.e. revealing a manager's private information and believed in by users, i.e. capable of affecting their decision when issued. This narrow definition is useful to address forecast credibility at its core. Neither a truthful forecast disclosure which is not believed, nor an untruthful forecast disclosure which is believed are likely to be economically efficient. In this light, empirical evidence consistent with managerial forecast disclosure having an impact on capital markets implies believability (e.g. Ajinkya and Gift, 1984; Clement et al., 2003; Lev and Penman, 1990). However, it is not evident whether market reactions follow from truthful forecasts, misinterpretations, heuristics or other factors. Empirical research also documents that audit quality and the threat of litigation influence both managers' decisions to disclose forecasts (Baginski et al., 2002; Skinner, 1997) and forecast accuracy (Clarkson, 2000; Jog and McConomy, 2003). Yet, these findings do not allow the drawing of direct inferences on forecast credibility in the sense described above. 
This study adopts economics of information to provide analytically-based assessment of the credibility of management forecasts in market and regulated settings. It synthesises and discusses analytical models to analyse managerial incentives, to truthfully report private forecast information that is also believed in by users. In market or unregulated settings, these incentives endogenously arise from strategic interaction with other parties formalised in cheap talk models. In regulated settings, credible forecast disclosure is affected by exogenous regulatory enforcement, including different types of external audit and liability. More specifically, the paper assesses the use of managerial forecasts per se, of supplementary disclosures on the forecast, and of safe harbour rules providing shelter from litigation. All of these issues are subject to debate after recent accounting scandals, and addressed from a regulator's, a preparer's and a user's point of view in this paper.

The analytically-based results challenge widespread notions on forecast credibility. Firstly, neither market nor regulation enforcement can assure truthful forecast disclosure. This implies that users should not overestimate the usefulness of forecasts. Credibility depends on restrictive conditions in a market setting which prevent managers from fully revealing private information. Secondly, audit and liability can only partly enhance credibility, but may induce adverse disclosure incentives. Approaches addressing managerial information ex ante, i.e. when disclosing a forecast, can contribute to credibility. However, ex post approaches, relying on comparing forecasted and realised outcomes, tend to be inadequate and to impose unintended consequences. Thirdly, while not required by most regulators, but observed empirically, supplementary disclosure of forecast methods and assumptions appear to be a fundamental measure to further credibility. Such disclosures can commit preparers to a specific way to meet forecasts and allow users to assess forecast plausibility. Fourthly, 
although perceived as a 'licence to lie' (Rogers and Stocken, 2005), safe harbour rules can contribute to forecast credibility by imposing a type of tort liability. These results are important for regulators, preparers and users in assessing forecast credibility.

The remainder is structured as follows. Section 2 discusses cheap talk models, while Section 3 addresses audit and litigation. Section 4 provides implications on the three controversial issues focussed on. Section 5 summarises and concludes.

\section{Forecast credibility in cheap talk models}

'Cheap talk' models consider communication settings where direct, plain communication, i.e. 'talk', is costless and non-binding, i.e. 'cheap'. Any message sent can affect payoffs only if a receiver responds to it (Aumann and Hart, 2003; Crawford and Sobel, 1982). Since the parties involved may or may not tell the truth and may or may not believe the messages, cheap talk models are particularly suitable for investigating forecast disclosure in market settings, i.e. settings without regulatory enforcement. Cheap talk models analyse how much information can be credibly transmitted due to strategic interaction of managers and other parties. The models yield equilibria in which managerial forecast disclosure is not credible and does not affect the users' actions. And they yield equilibria in which credible forecast disclosure is obtained (Charness, 2000; Farrell, 1993). Credible forecast disclosure can be identified as occurring under both single-period approaches addressing one specific forecast, and multi-period approaches, featuring a sequence of forecasts and realisations in a repeated cheap talk game. Each of the approaches will be considered in turn. 


\subsection{Single-period cheap talk}

Single-period approaches are based on the seminal work of Crawford and Sobel (1982). Accounting settings typically assume a manager whose utility function equals those of shareholders, e.g. aiming at high firm value. Credible communication requires a manager who balances rival disclosure incentives to almost same extent when taking her disclosure decision. These incentives stem from sending one message to multiple stockholders with different concerns, like shareholders and competitors. For instance, a manager might want to truthfully reveal her private information to shareholders while she is inclined to mislead (potential) competitors to avoid a decline in firm value (Fischer and Stocken, 2001; Gigler, 1994; Newman and Sansing, 1993).

Newman and Sansing (1993) provide a representative approach featuring an entry game. They assume a manager who holds perfect private information on future firm value. On the one hand, she seeks to pass all her private forecast information truthfully to the shareholders, to allow for optimal consumption. On the other hand, she wants to send an unfavourable (possibly random) forecast to the competitor, to deter costly entry in the product market lowering the incumbent firm's value. Given these incentives, fully revealing the private information is no part of an equilibrium. However, there are multiple partition equilibria with credible forecast disclosure. In these partition equilibria, a manager publishes a credible interval forecast, predicting a range of outcomes, truthfully covering the outcome implied by her private information, which is believed by all the outsiders. Gigler (1994) and Wagenhofer (2000) find similar results in settings featuring an existing Cournot duopoly or a competitor that is a prospective buyer of the firm, respectively. The main result is that credible forecast disclosure needs some noise, i.e. it is only possible in partitions. The finding is consistent with interval 
(or range) forecasts documented by empirical studies (for survey King et al., 1990). However, it is contradictive to results in discretionary disclosure models relying on a similar model structure and on verified disclosure. In these models, disclosure costs can prevent the publication of private information (Wagenhofer, 2000, for a discussion; Verrecchia, 2001, for a survey of discretionary disclosure models). Again consistent with empirical findings (e.g. Healy and Palepu, 2001), Newman and Sansing (1993) show that favourable forecasts can be credibly disclosed with less noise, i.e. in smaller partitions, compared to unfavourable forecasts.

Considering imperfect information available to the manager, Fischer and Stocken (2001) analyse the relation of the precision of the manager's private information and the precision of credible disclosure. In particular, they show that the fineness in a Blackwell (1951) sense, attributable to interval forecasts in credible partition equilibria, does not necessarily increase in the fineness of the manager's information. Consistent with results relying on verified disclosure (Penno, 1997; Richardson, 2001), this implies that more, or more precise, managerial information does not necessarily lead to more or more precise credible forecast disclosure.

Overall, single-period cheap talk approaches show that credible disclosure of a single forecast is possible, but linked to restrictive conditions. These particularly relate to the impossibility of fully revealing private information in a credible way and to common knowledge of managerial incentives to assess the borders of credible interval forecasts. Focussing on partition equilibria with credible communication, the finest equilibrium with the smallest partitions (in a given part of the full range of possible outcomes) is not necessarily obtained (Fischer and Stocken, 2001).[1] This suggests that only a little private forecast information will be disclosed credibly in a single-period context. 


\subsection{Multi-period cheap talk}

Multi-period approaches in the tradition of Sobel (1985) feature repeated cheap talk games. Unlike single-period approaches, they incorporate moral hazard and monitoring by outsiders. Monitoring usually implies a nominal/actual value comparison ex post. This contrasts single-period models which do not directly assess the realisation of the predicted variable. Credible communication can be obtained if the manager builds reputation through forecast disclosure that becomes classified as truthful ex post (Kim, 1996; Morris, 2001; Stocken, 2000).

Truthful disclosure of private forecast information is no equilibrium strategy in the setting considered by Morris (2001) and an exceptional equilibrium strategy in the approaches of Benabou and Laroque (1992) or Kim (1996). However, in a special accounting related setting, Stocken (2000) derives conditions yielding credible forecast disclosure. The model assumes a self-serving manager who may invest in one project with unknown future earnings in each period. She has to approach a representative investor for financing if the project shall be pursued. Early each period, the manager privately obtains imperfect information on the project's earnings. She can publish a (potentially random) forecast, implying favourable or unfavourable future earnings that might influence the investor's financing decision. At the end of each period, she has to release financial statements revealing the realised earnings with some noise. The latter provides the investor with an imperfect monitoring system to conduct a nominal/actual value comparison to assess the published forecast. No deviation detected increases a manager's reputation index, whereas a deviation decreases it. The investor uses the reputation index to assess the credibility of the recent forecast, i.e. whether to trust or to 
ignore it. Based on this mechanism, the investor can threaten the manager to ignore any forecast which lowers the expected managerial payoff in the repeated game.

In contrast to the single-period approaches discussed in the preceding section, there is no credible forecast disclosure in a single-period game in this setting because the manager is known to be self-serving and lacks rival disclosure incentives. However, given imperfect monitoring, credible forecast disclosure can be obtained in the repeated game. The key finding is that there is a perfect public equilibrium in which a manager nearly always discloses his private information truthfully. This result requires

(1) a manager who is not purely short-term orientated;

(2) a sufficient length of the review phase;

(3) the financial statements being sufficiently useful to conduct the nominal/actual value comparisons.

The first two conditions suggest that short-term interaction between the manager and the investor cannot impose truthful forecast disclosure. This is consistent with empirical studies which document strong incentives for misreporting in the presence of short-term speculation or high manager fluctuation (Headlock and Lumer, 1997; Nyman, 2005). Concerning the nominal/actual value comparison, relying on financial statements is crucial. While the third condition requires credible disclosure of specific data to conduct a nominal/actual value comparison ex post, this mechanism itself appears to be a heuristic. Section 3.1 discusses whether it is suitable to assess the credibility of former or future forecasts. 


\section{Forecast credibility through audit and liability}

Cheap talk models show that forecast disclosure can be credible without regulatory enforcement, but it is more common to see poor quality forecast disclosures, particularly when news is unfavourable. This results in calls for regulatory enforcement. Both external audit and the imposition of penalties for poor forecasts could potentially protect users of such statements.[2] Both enforcement mechanisms also have a preventative function, as a manager has to account for potential punishments when taking her disclosure decision. She will prefer truthful disclosure, as long as the threat of punishment is prohibitively high (Korn, 2004; Ronen and Yaari, 2001). Depending on the users' perceptions of these mechanisms and their effects on truthful disclosure, regulatory enforcement might improve the credibility of forecast disclosure. The effects differ with the particular type of audit and legal liability, and each of these will be reviewed in turn. An audit is defined as a nominal/actual value comparison conducted ex ante or ex post, i.e. before or after the realisation of the predicted variable is known, while liability systems are based upon the size of deviations detected by the audits (Ijiri, 1975; Posner, 1998).

\subsection{Audit}

Auditing forecasts at an ex ante stage lacks an observable nominal value to be compared to the actual, i.e. the forecasted value. The auditor has to revert to testing the completeness and consistency of forecast arguments and methods. As the assessment of this soft information remains vague, the audit is reduced to a test of plausibility that can prevent random or strongly biased forecast disclosure (Dev, 1973). Even this result is not necessarily obtained by engaging an auditor. 
As an agent, the auditor can give rise to agency problems discussed in agency and quasi rent models in the auditing literature (e.g. Ewert, 2004). The attestation by an untaught, lax, or dependent auditor is of poor or no value for forecast users. It can become precarious if the users only believe a misreporting manager due to the low quality audit. Such independence problems come to the fore when an auditor shall enforce going concern disclosures. In a simple model, Tucker and Matsumura (1998) show that an auditor will not insist on the disclosure of a probable corporate breakdown if disclosure can give rise to a self-fulfilling prophecy, or if the manager threatens to change the auditor, both impairing the incumbent auditor's quasi rents.

Like multi-period cheap talk models, parts of the prior literature rely on an audit at an ex post stage, i.e. a nominal/actual value comparison of the predicted (nominal) and the realised (actual) outcome, to assess the credibility of forecast disclosure (Arnold and Hope, 1974; Schrand and Elliott, 1998). The idea is simple: if no (a) material deviation is detected ex post the forecast is assessed to be truthfully (not truthfully) reflecting a manager's private information.

Stocken's (2000) model relies on deviations observed as the basis for the assessment of the credibility of future forecasts. More sophisticated approaches try to predict the direction and the extent of future distortions (Barefield, 1970; Eilon et al., 1973). From an economics of information point of view, such predictions appear speculative. Firstly, the extrapolation of past deviations into the future presumes a direct interrelation between the two which may have no theoretical basis. Secondly, the nominal/actual value comparison ex post assesses forecast accuracy, but not forecast credibility. It neither addresses whether the manager truthfully discloses private information, nor 
whether the users believe in the forecast before the realisation is known. Particularly, no (a) material deviation detected ex post does not allow one to conclude that the manager did (did not) truthfully disclose her private information due to incomplete foresight ex ante. Lacking a direct interrelation between forecast accuracy and credibility advises caution when relying on this approach and when interpreting empirical studies based on forecast accuracy.

There are also technical problems to conducting an audit ex post. Consider the example of an interval or a probabilistic forecast. It is not clear what the nominal value is. It might be the range of values covered by the forecast or a single value within the range, like the expected value or the mode. The choice affects the likelihood and the size of ex post deviations. Or suppose the actual value, like realised earnings of a certain project, is at the manager's discretion. If the actual value is not observable or not believed in, no direct comparison can be conducted.[3] Taken together, there are two ways a manager can reduce the probability or the size of a deviation. Firstly, she may disclose noisy forecasts which do not reveal her exact private information, supplementing the incentives formalised in single-period cheap talk models. Secondly, she may use discretion to manage the realised values towards the forecast values (Dutta and Gigler, 2002). Both are consistent with empirical evidence on earnings management (Burgstahler and Eames, 2003; Matsumoto, 2002). A particular problem relates to going concern disclosures. As with any risk, if a manager does not disclose the risk of failure and the risk does not materialise, its former existence does not become transparent ex post. However, if the risk does materialise and the firm fails, the audit ex post is too late to be useful for the forecast users when there is no suitable system of liability. 


\subsection{Liability}

In a system of strict liability, a manager disclosing a forecast causing damage to the users is liable, regardless of any default on his part. Assuming decision-usefulness, strict liability punishes a manager whenever the realised outcome differs from the predicted outcome. Since such deviations can occur if the manager truthfully discloses her exact private information, fully revealing private information is not necessarily her dominant disclosure strategy to prevent or reduce expected litigation cost. This is consistent with empirical studies that find managers omitting forecast disclosure (Healy and Palepu, 2001; Skinner, 1997) and disclosing noisy forecasts (Bamber and Cheon, 1998; King et al., 1990) in the presence of strict liability. Thus, relying on an audit ex post, strict liability is - at least potentially - counterproductive to encourage informative forecast disclosure.

Unlike strict liability, tort liability holds a manager liable for damage caused by forecast disclosure only if there is default on her part. One can interpret default as a deviation of the forecasted value from the value truthfully reflecting private information. A damage claimed initiates an assessment as to whether the manager did reveal her private information in the published forecast. This assessment is technically similar to an audit ex ante, as discussed in the preceding section, but conducted at a later point in time. Tort liability, thus, can assist credible forecast disclosure if the expected costs of litigation are sufficiently large to threaten the manager. However, the assessment of a forecast by an audit remains vague, giving rise to alpha errors, i.e. assuming truthful disclosure of private information as untruthful, and beta errors, i.e. assuming untruthful disclosure as truthful. Thus, the system will not fully prevent untruthful and biased forecasts as shown in analytic models (Korn, 2004; Ronen and Yaari, 2001). This result 
is consistent with empirical studies documenting the withholding, or noisy publication, of forecasts in a system of tort liability (Johnson et al., 2001).

Considering tort liability, Trueman (1997) formalises some of the above incentives in a setting with an affirmative duty to disclose forecasts where users are uncertain whether the manager has forecast information to disclose or not (Dye, 1985). If a forecast is withheld or disclosed with noise and fully revealing private information would have had a negative impact on the firm's price, the manager can be successfully sued by lawyers of shareholders who purchased shares at an inflated price. A court only discovers withholding of private information with a certain probability, giving rise to a beta error. An alpha error is outside the scope of the model. The key finding is that a manager will disclose sufficiently favourable and sufficiently unfavourable forecasts truthfully and (in most cases apart from very unfavourable forecasts) without noise. But even within the model, this result does not hold for each set of parameters. While Trueman (1997, p.188) rules out such settings to be 'clearly unrealistic', it can be analytically shown that unfavourable forecasts will be withheld, whenever the manger puts more weight on the firm's price, relative to the damage award. Yet, this is likely in the presence of capital market pressure or large stock-based compensation, thereby challenging Trueman's finding.

\section{Implications}

Cheap talk models imply that the credibility of managerial forecast disclosure is linked to very restrictive conditions in a market setting, while audit and litigation systems can increase or can lessen, but cannot eliminate this deficit in a regulated setting. The results 
of the last two sections suggest the reassessment of common notions on forecast disclosure. Major implications concern the use of managerial forecasts per se assumed to be decision-useful information, of disclosures supplementing forecasts recommended by economic literature for decades and recently addressed by empirical research, and safe harbour rules assessed as a 'licence to lie' in the accounting fraud debate. These controversial topics are each addressed from a regulator's, a preparer's and a user's perspective.

\subsection{Use of managerial forecasts}

Managerial forecast disclosure is assumed to be highly decision-useful for users of financial reporting (e.g. AICPA, 1994; Hirst et al., 2007; Till, 1980). In contrast, cheap talk models show that credible forecast disclosure is crucial and can prevent a manager from fully revealing her private information. In particular, unfavourable forecasts will be withheld, disclosed with noise or misreported, thereby challenging the early warning function of risk reporting. Enforcement regulation can have ambiguous effects. While strict liability, relying on an audit ex post, tends to impose adverse forecast disclosure incentives, an audit ex ante and a system of tort liability can contribute to the credibility of published forecasts.

Although there are arguments in favour of mandatory forecast disclosure, e.g. related to improved corporate information and governance systems or disciplining market effects (Gonedes et al., 1976), the problems of credibility reaffirm most regulators - with the German Accounting Standards Board being the most notable exception - not to require forecasts in management reports.[4] Acknowledging non-verifiability of forecasts, the SEC had prohibited managerial forecast disclosure until the early 1970s, primarily to 
protect users from potentially biased and misleading information (Till, 1980). When relying on voluntary forecasts now, regulatory bodies rather aim at protecting preparers from litigation (AICPA, 1994; IASB, 2005) than at protecting users from untruthful managerial forecasts. This is noteworthy because international standard-setters do not stress litigation concerns when relying on partly mandatory fair value measurement, although it requires estimates and forecasts if market prices are unobservable. What emerges is a differentiation in respect to forecast elements

(1) in financial statements, which users cannot easily individually identify in most cases;

(2) in management reports, which can be easily identified in general.

Thus, identifiability seems to be a reason for regulators' concerns on forecast litigation focusing on individual forecasts.

While neither the market nor regulatory enforcement can prevent misreporting forecasts, a preparer who wants to credibly disclose private forecast information faces the problem of how to do so. Single-period cheap talk models imply disclosure of private information with some noise. But noisy forecasts can put a cost on the preparer, when detected in a regulated setting. As market mechanisms persist in the presence of audit and litigation, a dilemma emerges. Moreover, the threat of alpha errors in a court's assessment can even punish truthfully reporting managers providing incentives not to disclose a forecast. Once given a decision to disclose a forecast, a manager may exploit market heuristics, like reliance on forecast accuracy ex post, allowing her to build a reputation as assumed in multi-period cheap talk models. Or she can exploit signalling mechanisms, like engaging high quality auditors, to enhance a user's belief in the forecast (Mercer, 2004). Consistent with empirical findings, these measures are capable of affecting the believability of forecasts (Clement et al., 2003; Kent and Ung, 2003; 
Hutton and Stocken, 2007). However, they cannot assure forecast credibility incorporating truthful disclosure of private forecast information, as discussed in Section 3.

The problems of forecast credibility in both market and regulated settings advise users not to overestimate the decision-usefulness of managerial forecasts and to exercise care when relying on them. Unlike what is assumed in the analytical models discussed, forecasts in management reports are only one source of information. In particular, management reports are to provide a managerial perspective that supplements the financial statements and allows users to build their own expectations of the entity's future development. Management forecasts should, therefore, be seen as assisting users to perform this task, rather than becoming a substitute for their own assessment.

\subsection{Use of supplementary disclosures}

To contribute to forecast credibility, the literature has been suggesting that supplementary disclosures and explanations on forecast arguments and methods be provided (Dev, 1973; Mallinson, 1974; Mercer, 2004). Unlike a disclosed forecast per se, supplementary disclosures can be verifiable. While a comprehensive economicsbased theory on supplementary disclosures accompanying managerial forecasts does not exist, reasoning along the lines of audit ex ante and tort liability, implies that such disclosures can enhance forecast credibility. The basic idea is that supplementary disclosures provide partly verifiable information, assisting users to assess the plausibility of both, a forecast ex ante and nominal/actual deviations ex post, thereby imposing incentives for truthful disclosure. 
Although forecasts are not mandatory in most accounting regimes, regulatory bodies recommend supplementary information on forecasts when disclosed (AICPA, 1994; IASB, 2005). In Germany, where forecast disclosure is compulsory, forecast assumptions have to be disclosed (Sections 289(1), 315(1) German Commercial Code; GAS 15). Supplementary disclosures in particular, can assist the assessments of a forecast by users and in a system of tort liability.

A preparer's decision to report a forecast and supplementary disclosures on the forecast are interrelated and depend on incentives. A preparer interested in credible forecast disclosure can choose to provide supplementary disclosures, thereby committing to a specific way to reach forecasted values. In a similar vein, disaggregated forecasts on line items supplementing, e.g. an earnings forecast can commit the preparer (Hirst et al., 2007). While the commitment reduces discretion to manage outcomes ex post to meet forecasted values, two countervailing effects on litigation emerge. Supplementary disclosures can help to reduce the risk of alpha errors in a system of tort liability. But given the commitment, the threat of litigation can increase, based on nominal/actual deviations in forecast arguments observed, even if the forecast value was met. Empirical research implies that managers are particularly inclined to provide supplementary disclosures when forecasts are very unfavourable or very favourable. Baginski et al. (2004) document more explanations accompanying bad-news forecasts to legitimate unfavourable developments with external factors. In contrast, Hutton et al. (2003) find that managers are more likely to supplement good-news forecasts with verifiable forward-looking disclosures to convince users of favourable prospects. Maintaining voluntary forecast disclosure, but requiring supplementary disclosures if a manager chooses to report a forecast implies two effects. Firstly, as a manager has to explain her forecast, she may be less inclined to disclose random or strongly biased forecasts. 
Secondly, commitment and countervailing effects of liability can make her choose to withhold private forecast information which she would partly release when no supplementary disclosure was required.

From a user's perspective, this self-selection, going beyond self-selection in preparers' decisions to issue a forecast per se, can be beneficial. It tends to prevent random forecast disclosure, while supplementary disclosures allow for an own assessment of the plausibility of a forecast similar to an audit ex ante, thereby contributing to forecast credibility. Consistent with this reasoning, a growing body of recent empirical research finds an association between supplementary disclosures with users' and capital market reactions suggesting that they are incrementally informative (Baginski et al., 2004; Hutton et al., 2003; Hutton and Stocken, 2007).

\subsection{Use of safe harbour rules}

Supplementary disclosures are also important when considering safe harbour rules, which have been criticised as a 'licence to lie' in the context of recent accounting scandals (Cunningham, 2004; Enron Watchdog, 2005; Sunder, 2003). Most notably in the USA, 'safe harbours' provide shelter from liability according to Rule $10 \mathrm{~b}-5$ of the Securities and Exchange Act for certain forward-looking statements, particularly forecasts (Avery, 1996; Ripken, 2005; Robertson, 1999). According to the Private 
Securities Litigation Reform Act of 1995, Sec. 27A of the Securities Act and Sec. 21E of the Securities and Exchange Act, liability is excluded if and to the extent that the forward-looking statement

(1) is immaterial or

(2) is labelled as such and accompanied by a meaningful cautionary statement identifying important factors which could cause deviations ex post or (3) was not made with actual knowledge that the statement was false or misleading.

According to the wording of the law, safe harbour protection only demands one of the above criteria to be met. At first sight, regulation implies that even a fraudulent manager cannot be found liable if she issued an adequate cautionary statement. This gives rise to the critique: 'As long as such statements were clearly labelled to be forward looking, the management could not be held liable for errors in such statements.' (Sunder, 2003, p.12) In practice, however, lawyers will question whether the cautionary statement was meaningful and court action will focus on non-forward-looking information included in the cautionary statement, unprotected by a safe harbour (Johnson et al., 2007; Robertson, 1999). Thus, clearly labelling a forecast as such does not immediately protect from liability even in the presence of safe harbour rules. While criterion (1) rules out litigation for a forecast which cannot be decision-useful and thus cannot cause a damage, criterion (2) has rather formal character, but can further credibility, depending on the supplementary disclosures included in the cautionary statement. Yet, criterion (3) appears to be the most important to exclude liability. What emerges is similar to a system of tort liability found suitable to contribute to forecast credibility in Section 3.2, as opposed to a system of strict liability under Rule 10b-5 Securities and Exchange Act. 
Empirical evidence on effects of introducing safe harbour provisions on a preparer's forecast disclosure is largely consistent with the analytical results on liability. Most notably, Johnson et al. (2001) analyse a large sample of software, hardware, and pharmaceutical firms. They document that the introduction of safe harbour provisions led to an increase in the mean number of forecasts issued and in the frequency of shortterm bad news forecasts and long-term forecasts. However, there is no evidence that disclosures changed towards quantitative, narrow range or point forecasts. This is, again, consistent with the outlined managerial incentives to publish noisy forecasts to avoid ex post deviations.

In contrast to recent criticism, these results suggest that users should not interpret safe harbour rules as a 'licence to lie'. Rather they impose a system of tort liability appropriate to contributing to forecast credibility. Despite this contribution, the criticism on safe harbour rules might have helped to make unsophisticated users aware of the issue of managerial forecast credibility, while reaffirming sophisticated users not to overestimate the decision-usefulness of forecasts, even in a regulated environment.

\section{Conclusions}

This paper presents an analytically-based assessment of credibility of management forecasts as an example of communication of non-verifiable information. The findings show that credible forecast communication is possible in a market setting. However, it is linked to restrictive conditions, even preventing a manager from truthfully revealing private information without noise. Among the regulatory enforcement mechanisms, ex ante approaches, including the typical audit and tort liability, can contribute to forecast 
credibility. In contrast, ex post approaches are conceptually inadequate to contribute to forecast credibility, but tend to induce adverse disclosure incentives. Overall results suggest that the usefulness of a managerial forecast should not be overestimated, as neither market nor regulatory enforcement can overcome the problems related to nonverifiability. The discussion yields important implications for regulators, preparers and users, partly challenging common notions:

(1) The issue of credibility reaffirms the fact that regulators should not mandate forecasts in management reports. But it casts doubt on the growing reliance on fair value measurement in financial statements, which require forecasts when market prices for assets and liabilities are not observable. Although largely criticised, safe harbour rules, inducing a type of tort liability, are generally capable of contributing to forecast credibility.

(2) Large restrictions and few possibilities to credibly report forecasts in an economics of information setting suggest that preparers need to exploit market heuristics to build a reputation to further the users' belief in truthful forecast disclosure. However, supplementary disclosures on forecasts may be a fundamental measure to contribute to forecast credibility. They can commit the preparer to a specific way to meet a forecast and allow users to assess its plausibility and sensitivity.

(3) Forecasts are non-verifiable at an ex ante stage. Since managers may have incentives to misreport and both market and regulatory mechanisms can only partly contribute to credibility, users should carefully consider the decision-usefulness of managerial forecasts. These forecasts can assist users to build expectations of an entity's future development, but they are not to be considered as a substitute for the users' own assessment. 
The results have at least three important implications for empirical research. Firstly, results suggest that great weight should be not be given to forecasts per se in studies relying on disclosure scores, but to differentiate forecasts with and without supplementary disclosures.[5] Secondly, the paper can help in formulating a testable hypothesis, e.g. on the relation of ex post deviations and believability or the interaction of market and regulatory enforcement on patterns of forecast disclosure. By exploiting different institutional settings to investigate these issues, empirical studies will provide further indirect evidence on the interaction of truthfully revealing private information and forecast believability. Thirdly, to assess forecast credibility more directly, experimental research appears more promising than research relying on capital market data.

\section{Acknowledgements}

The author thanks two anonymous reviewers, Morad Benyoucef, Silvia Hettich, Margaret Woods, seminar participants at the Ludwig-Maximilians-University of Munich and participants of the 27th Annual Conference of the European Accounting Association in Prague, for their constructive criticism and suggestions for improvements. 


\section{References}

Ajinkya, B.B. and Gift, M.J. (1984) 'Corporate managers' earnings forecasts and symmetrical adjustments of market expectations', Journal of Accounting Research, Vol. 22, No. 2, pp.425-444.

American Institute of Certified Public Accountants (AICPA) (1994) Improving Business Reporting: A Customer Focus, New York: AICPA.

Arnold, J. and Hope, A. (1974) 'Reporting business performance', Accounting and Business Research, Vol. 5, No. 1, pp.96-105.

Aumann, R.J. and Hart, S. (2003) 'Long cheap talk', Econometrica, Vol. 71, No. 6, pp.1619-1660.

Avery, J.W. (1996) 'Securities litigation reform: the long way and winding road to the Private Securities Litigation Reform Act of 1995', The Business Lawyer, Vol. 51, No. 2, pp.335-378.

Baginski, S.P., Hassell, J.M. and Kimbrough, M.D. (2002) 'The effect of legal environment on voluntary disclosure: evidence from management earnings forecasts issued in US and Canadian markets', The Accounting Review, Vol. 77, No. 1, pp.25-50.

Bamber, L.S. and Cheon, Y.S. (1998) 'Discretionary management earnings forecast disclosures: antecedents and outcomes associated with forecast venue and forecast specifity choices', Journal of Accounting Research, Vol. 36, No. 2, pp.167-190.

Barefield, R.M. (1970) 'A model of forecast biasing behavior', The Accounting Review, Vol. 45, No. 3, pp.490-501.

Benabou, R. and Laroque, G. (1992) 'Using privileged information to manipulate markets: insiders, gurus, and credibility', The Quarterly Journal of Economics, Vol. 107, No. 3, pp.921-958.

Blackwell, D. (1951) 'Comparison of experiments', in J. Neyman (Ed.) Proceedings of the Second Berkeley Symposium on Mathematical Statistics and Probability, Berkeley and Los Angeles, CA: University of California Press, pp.93-102.

Burgstahler, D.C. and Eames, M.J. (2003) 'Earnings management to avoid losses and earnings decreases: are analysts fooled?', Contemporary Accounting Research, Vol. 20, No. 2, pp.253-294.

Charness, G. (2000) 'Self-serving cheap talk: a test of Aumann's conjecture', Games and Economic Behaviour, Vol. 33, No. 2, pp.177-194.

Clarkson, P.M. (2000) 'Auditor quality and the accuracy of management earnings forecasts', Contemporary Accounting Research, Vol. 17, No. 4, pp.595-622.

Clement, M., Frankel, R. and Miller, J. (2003) 'Confirming management earnings forecasts, earnings uncertainty, and stock returns', Journal of Accounting Research, Vol. 41, No. 4, pp.653-679.

Crawford, V. and Sobel, J. (1982) 'Strategic information transmission', Econometrica, Vol. 50, No. 6, pp.1431-1451.

Cunningham, L.A. (2004) 'Revisiting the role of the future in accounting reform', Working Paper, Boston College.

Dev, S. (1973) 'Problems in interpreting prospectus profit forecasts', Accounting and Business Research, Vol. 3, No. 1, pp.110-116.

Dobler, M. (2005) 'National and international developments in risk reporting: may the German Accounting Standard 5 lead the way internationally?', German Law Journal, Vol. 6, No. 8, pp.1191-1200.

Dutta, S. and Gigler, F. (2002) 'The effect of earnings forecasts on earnings management', Journal of Accounting Research, Vol. 40, No. 3, pp.631-655. 
Dye, R.A. (1985) 'Disclosure of nonproprietary information', Journal of Accounting Research, Vol. 23, No. 1, pp.123-145.

Eilon, S., Tilley, R.P. and Gold, B. (1973) 'Measuring the quality of economic forecasts', OMEGA - The International Journal of Management Science, Vol. 1, No. 2, pp.217-227.

Enron Watchdog (2005) Prevent Financial Fraud: Repeal the Accountant Immunity Act - the 1995 Private Securities Litigation Reform Act (PSLRA). www.enronwatchdog.org/topreforms/topreforms5.html.

Ewert, R. (2004) 'Audit regulation, audit quality, and audit research in the post-Enron era: an analysis of nonaudit services', in C. Leuz, D. Pfaff and A. Hopwood (Eds) The Economics and Politics of Accounting, Oxford et al.: Oxford University Press, pp.149-163.

Farrell, J. (1993) 'Meaning and credibility in cheap talk-games', Games and Economic Behavior, Vol. 5, No. 4, pp.514-531.

Fischer, P.E. and Stocken, P.C. (2001) 'Imperfect information and credible communication', Journal of Accounting Research, Vol. 39, No. 1, pp.119-134.

Gigler, F. (1994) 'Self-enforcing voluntary disclosures', Journal of Accounting Research, Vol. 32, No. 2, pp.224-240.

Gonedes, N.J., Dopuch, N. and Penman, S.H. (1976) 'Disclosure rules, informationproduction, and capital market equilibrium: the case of forecast disclosure rules', Journal of Accounting Research, Vol. 14, No. 1, pp.89-137.

Headlock, C.J. and Lumer, G.B. (1997) 'Compensation, turnover, and top management incentives - historical evidence', Journal of Business, Vol. 70, No. 2, pp.153-187.

Healy, P.M. and Palepu, K.G. (2001) 'Information asymmetry, corporate disclosure, and the capital markets: a review of the empirical disclosure literature', Journal of Accounting and Economics, Vol. 31, Nos. 1-3, pp.405-440.

Hirst, D.E., Koonce, L. and Venkataraman, S. (2007) 'How disaggregation enhances the credibility of management earnings forecasts', Journal of Accounting Research, Vol. 45, No. 4, pp.811-837.

Hutton, A.P. and Stocken, P.J. (2007) 'Effect of reputation on the credibility of management forecasts', Working Paper, Dartmouth College.

Hutton, A.P., Miller, G. and Skinner, D.J. (2003) 'The role of supplementary statements with management earnings forecasts', Journal of Accounting Research, Vol. 41, No. 5, pp.867-890.

Ijiri, Y.C. (1975) Theory of Accounting Measurement, Sarasota: AAA.

International Accounting Standards Board (IASB) (2005) Discussion Paper: Management Commentary, London: IASB.

Jog, V. and McConomy, B.J. (2003) 'Voluntary disclosure of management earnings forecasts in IPO prospectuses', Journal of Business Finance and Accounting, Vol. 30, Nos. 1-2, pp.125-167.

Johnson, M.F., Kasznik, R. and Nelson, K.K. (2001) 'The impact of securities litigation reform on the disclosure of forward-looking information by high technology firms', Journal of Accounting Research, Vol. 39, No. 2, pp.297-327.

Johnson, M.F., Nelson, K.K. and Pritchard, A.C. (2007) 'Do the merits matter more? The impact of the Private Securities Litigation Reform Act', The Journal of Law, Economics, and Organization, Vol. 23, No. 3, pp.627-652.

Kent, P. and Ung, K. (2003) 'Voluntary disclosure of forward-looking earnings information in Australia', Australian Journal of Management, Vol. 28, No. 3, pp.273-285.

Kim, J-Y. (1996) 'Cheap talk and reputation in repeated pretrial negotiation', RAND Journal of Economics, Vol. 27, No. 4, pp.787-802. 
King, R., Pownall, G. and Waymire, G. (1990) 'Expectation adjustments via timely management forecasts: review, synthesis, and suggestions for future research', Journal of Accounting Literature, Vol. 9, No. 1, pp.113-144.

Korn, E. (2004) 'Voluntary disclosure of partially verifiable information', Schmalenbach Business Review, Vol. 56, No. 2, pp.139-163.

Lev, B. and Penman, S.H. (1990) 'Voluntary forecast disclosure, nondisclosure, and stock prices', Journal of Accounting Research, Vol. 28, No. 1, pp.49-76.

Mallinson, A.H. (1974) 'A risk analysis approach to profit forecasts', Accounting and Business Research, Vol. 4, No. 1, pp.83-95.

Matsumoto, D.A. (2002) 'Management's incentives to avoid negative earnings surprises', The Accounting Review, Vol. 77, No. 3, pp.483-514.

Mercer, M. (2004) 'How do investors assess the credibility of management disclosures?', Accounting Horizons, Vol. 18, September, pp.185-196.

Morris, S. (2001) 'Political correctness', Journal of Political Economy, Vol. 109, No. 2 , pp.231-265.

Newman, P. and Sansing, R. (1993) 'Disclosure policies with multiple users', Journal of Accounting Research, Vol. 31, No. 1, pp.92-112.

Nyman, I. (2005) 'Stock market speculation and managerial myopia', Review of Financial Economics, Vol. 14, No. 1, pp.61-79.

Penno, M. (1997) 'Information quality and voluntary disclosure', The Accounting Review, Vol. 72, No. 2, pp.275-284.

Posner, R.A. (1998) Economic Analysis of Law, 5th edition, New York: Aspen Law \& Business.

Richardson, S. (2001) 'Discretionary disclosure: a note', Abacus, Vol. 37, No. 2, pp.233-247.

Ripken, S.K. (2005) 'Predictions, projections, and precautions: conveying cautionary warnings in corporate forward-looking statements', University of Illinois Law Review, Vol. 2005, No. 4, pp.929-987.

Robertson, R.A. (1999) 'In search of the perfect mutual fund prospectus', The Business Lawyer, Vol. 54, February, pp.461-498.

Rogers, J.L. and Stocken, P.C. (2005) 'Credibility of management forecasts', The Accounting Review, Vol. 80, No. 4, pp.1233-1260.

Ronen, J. and Yaari, V. (2001) 'Incentives for voluntary disclosure', Journal of Financial Markets, Vol. 4, No. 4, pp.309-357.

Schrand, C.M. and Elliott, J.A. (1998) 'Risk and financial reporting: a summary of the discussion at the 1997 AAA/FASB conference', Accounting Horizons, Vol. 12, September, pp.271-282.

Skinner, D.J. (1997) 'Earnings disclosures and stockholder lawsuits', Journal of Accounting and Economics, Vol. 23, No. 3, pp.249-282.

Sobel, J. (1985) 'A theory of credibility', Review of Economic Studies, Vol. 52, No. 4, pp.557-573.

Stocken, P.C. (2000) 'Credibility of voluntary disclosure', RAND Journal of Economics, Vol. 31, No. 2, pp.359-374.

Sunder, S. (2003) 'Rethinking the structure of accounting and auditing', Indian Accounting Review, Vol. 7, No. 1, pp.1-15.

Till, K. (1980) 'The SEC safe harbor for forecasts: a step in the right direction?', Duke Law Journal, Vol. 1980, No. 3, pp.607-640.

Trueman, B. (1997) 'Managerial disclosures and shareholder litigation', Review of Accounting Studies, Vol. 2, No. 2, pp.181-199.

Tucker, R.R. and Matsumura, E.M. (1998) 'Going concern judgements: an economic perspective', Behavioral Research in Accounting, Vol. 10, pp.178-217. 
Verrecchia, R.E. (2001) 'Essays on disclosure', Journal of Accounting and Economics, Vol. 32, No. 1, pp.97-180.

Wagenhofer, A. (2000) 'Disclosure of proprietary information in the course of an acquisition', Accounting and Business Research, Vol. 31, No. 1, pp.57-69. 


\section{Notes}

[1] Newman and Sansing (1993) show that partition equilibria cannot necessarily be ordered according to the Pareto criterion. However, the Pareto criterion is inadequate to assess the 'usefulness' of perfect Bayesian equilibria as long as players are exclusively interested in their own payoffs. Then, possible Pareto improvements do not induce a change in individual behaviour.

[2] Although internal and external audit do not materially differ in technical respects, if information sources provided to audit the forecast are similar, this paper refers to external audit (at ex ante and ex post stages).

[3] A related issue arises, if the definition of a forecasted item is ambiguous and cannot be directly linked to a realised item as disclosed and defined under GAAP.

[4] While the SEC requires some forward-looking information in the MD\&A (FRR 36 and 48), the Management Commentary proposed by the IASB (2005) explicitly does not require forecasts. The German Accounting Standards GAS 5 on risk reporting and GAS 15 on management reporting require forecasts on the entity's expected future development with its material risks and chances in the management report (Dobler, 2005). However, up to now these standards have not been well enforced and litigation for forecasts in German management reports is still undeveloped.

[5] It is known that disclosure scores rather measure disclosure quantity than disclosure quality. They have to rely on the hypothesis that disclosure quantity and quality are positively related to draw inferences on disclosure quality. This proves particularly critical when considering managerial forecasts. Including a forecast, e.g., in a management report c.p. increases disclosure quantity. But it is unclear whether it increases disclosure quality, however measured. 